\title{
Ørefigenmysteriet
}

\section{Tre tyske eksempler på intertekstualitet i satirens tjeneste}

Selv om ingen vistnok har foreslaet at tolke Johannes hallucinationer på Patmos som satire, er der så meget samfundskritik $i$ äbenbaringen, at der gàr en lige linje til Dantes Inferno, hvor laserne kunne godte sig over de straffe for eksempel Firenzes kendte borgere måtte lide i Helvede. Nogle straffe afspejlede synderens brode; spaimand blev i eksempelvis straffet ved at skulle gå baglans uden at dreje hovedet.

Mens tredvearskrigen herger i Europa, lader teologen og forfatteren Johan Michael Moscherosh en jeg-fortaller gå i samme spor og fortalle, at digtere og musikere pines $i$ Helvede ved at skulle hore på deres egne varker. Bogen, der havde et fransk forlag, hedder Wunderbahre Satyrische gesichte Verteutscht durch Philander von Sittewalt og udkom i 1640. Den har teologen, forfatteren og debattoren Johannes Lassenius givetvis lest, inden han skrev sin satire, Arcana, som affodte et stridskrift af en "Schüler aus Quedlinburg", Johan Christoffer Kilian, der her citerer William Ames'bitre, sarkastiske kritik affornaunte Lassenius. De to stredes om, hvorvidt Quakerne, en skotsk protestantisk antiautoriter sekt, kunne retfardiggøres.

Debat, strid og kritik har det syttende arhundrede ikke manglet og sadan far teksterne mange beroringspunkter.

Lassenius brugte imidlertid intertekstualiteten til at indga en kontrakt med laseren, hvor man skal huske at lase det, der stair med småt ...

\section{af cand.mag. Knud Haugmark}

I samlingen på Kongelige Bibliotek findes tre bøger, der alle blev udgivet i 1666. De to er forskellige udgaver af samme tekst, som i almindelighed benævnes "Arcana." ${ }^{1}$ Forfatteren er den i Rostock uddannede teolog Johannes Lassenius, f. 1636, som i 1666 var nytiltrådt rektor for latinskolen i Itzehoe. Christian den Femte skulle nogle år senere hente ham til København, hvor han gjorde en god figur som både ledende teolog på universitetet og præst ved Petri tyske kirke. Han døde i 1692 og blev gravsat $i$ kapellet her under et prægtigt epitafium.

Det tredje værk er en pamflet på bare tolv sider med et frådende angreb på Ar- cana og Lassenius. Forfatteren kalder sig Johannes Christophorus Kilian², formodentlig et pseudonym.

I det følgende skal jeg forsøge at afdække hvem disse to personer er og pege på en mulig inspirationskilde for Lassenius' Arcana.

I tidens stil indleder Lassenius sit værk med en formfuldendt dedikation:

$$
\begin{gathered}
\text { "Til den hæderlige, fromme } \\
\text { og vidt berømte } \\
\text { Herr NEMO } \\
\text { af Allerhausen. }
\end{gathered}
$$

Min trofaste velgører og ven ønsker jeg alt, hvad der gavner hans velstand og lykke"3 


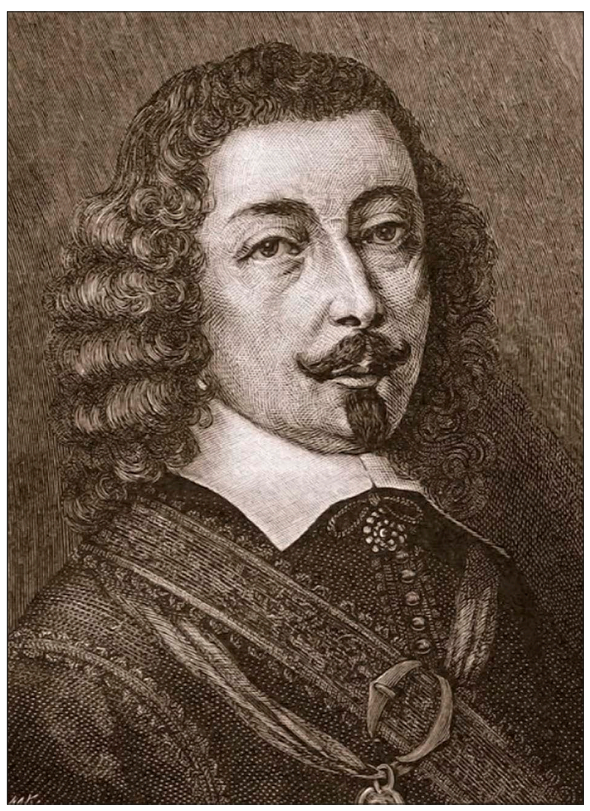

Johann Michael Moscherosch (1601-1669) udgav mange af sine ofte satiriske tekster under pseudonymet Philander. Kobberstik, $<$ portrait.kaar.at $>$.

NEMO betyder som bekendt "ingen" på latin, altså: "til herr Ingen fra alle steder". Her skriver han bl.a.

"Vidt berømte Herr NEMO.

De skal slet ikke undre Dem over, at jeg lader efterfølgende afhandling være tilegnet Deres vidt berømte navn.

Det sker efter råd fra mange af dem, som giver sig ud for at være mine venner, for jeg har indtil nu af gammel vane tilegnet mine skrifter personer fra både den højere klasse og af middelstanden, og såvel lagt mig på maven og rullet mig $\mathrm{i}$ støvet, idet jeg efter bedste evne roste mine værker. Ikke desto mindre har jeg kun fået til svar, at INGEN vil være mig venligt stemt og fremover stå på min side." ${ }^{.4}$
Lassenius holder den høje stil, mens han selvironisk gør op med tidens smiskende tilegnelser til rigere og mere indflydelsesrige standspersoner, som i heldigste fald kunne gengælde rosen med et net, lille embede. Adressen kunne være Johann Michael Moscherosch, som kan være ophavsmand til denne fiffige dedikation, men herom senere. Referencen til Odysseus, der snedigt, ved at kalde sig "Ingen", snød Kyklopen og slap væk fra fangenskabet med sine mænd, er iøjenfaldende.

Dedikationen afløses af en fortale, hvor Lassenius bl.a. skriver:

"Nogle vil mene, at jeg har hentydet til den ene eller spiddet den anden.

Hvis den gemenhed skulle ramme mig, at mange sure læsere forvandler mine teksters sødeste honning til den rene gift, kan jeg bevidne for verden, at disse samtaler ikke handler om kendte personer, og at jeg hverken skandaliserer eller hænger nogen ud."

Den slags ansvarsfraskrivelser betyder almindeligvis det modsatte, nemlig at Gud og hvermand i det følgende optræder i genkendelig form.

Fortalen munder ud i "Første samtale" af $i$ alt fire imellem to personer på en ubestemt middelhavsø tilsyneladende en gang i antikken. Men først afleverer Lassenius en dommedagsvision, som med sit usminkede angreb på myndighederne danner bagtæppe for hele værket: ${ }^{6}$

“Det så sort ud for verden, og det lå de, der følte ansvar for fremtiden, stærkt på sinde. Oversvømmelser, opstande, hvirvelstorme og nye epidemier dukkede op over det hele og skræmte menneskene. Oven i købet havde myndighederne overvåget befolk- 
ningen og smedet rænker i det skjulte, så den plagede menneskehed var måske bedre tjent med at blive opslugt af jorden i et altomfattende jordskælv frem for at leve videre i al den elendighed."7

Herefter begynder en letflydende fortælling om to venner, Philalethes og Philistoreon, som mødes efter lang tid, tydeligt glade over gensynet. Deres samtaler foregår på tysk og latin og indrammes af hverdagshændelser.

Philalethes, der som Lassenius selv må være præst og digter, er frustreret over, at han ikke kan finde lydhørhed for sit moralske/kristne budskab i sine skrifter. Han giver den som overset geni og jamrer som en gammeltestamentelig profet:

"Jeg, fjog, der har prædiket sandheden både i tale og skrift. Nu har du, Herre, bragt mig i vildrede.

Men alle tings Herre, det blir værre og værre, så slå nu igen, luk kæften på de falske profeter og tag hævn for dit folks nederlag. Jeg skal nok lide i stilhed og hverken murre eller længes efter fortidens overflod. Jeg tror fuldt og fast på, at den gode Gud lige som i ørkenen vil sørge for mad på bordet.”

De følgende ca. 100 sider er en egal beskrivelse af de to mænds venskab. De slentrer omkring i en lille havneby, og Philistoreon fortæller, at man på markedet kan støde på:

"alle mulige forkellige varer som sælges af fremmede købmænd, som tiltrækker komedianter, gøglere og taskespillere, kvaksalvere og tandbrækkere, tombolanter og den slags pak, som ikke bestiller andet end at hive penge ud af folk i denne by."
Hverken læger eller tandlæger står i høj kurs hos Lassenius.

De to venner begiver sig væk fra byen, hvor de støder på tre orientalske troldmænd, som sælger magiske briller, hatte og frakker til alle mulige standspersoner.

Mens Philistoreon orienterer sig, står Philalethes måbende tilbage, indtil vennen kommer hen og fortæller:

"Hatten har den ene virkning, under påberåbelse af retten at lukke kæften på folk, at bilde dem ind, at alt, hvad der kommer ud af munden på en sådan hattebærende papirnusser, er som englenes og gudernes himmelske tale. Men under hatten gemmer sig den værste ondskab, så det er ikke bar uld, men et får, man finder der. Både den ene og den anden er kommet højt til vejrs med sådan en hat på hovedet.

Ved disse hatte har mere end ét kongerige eller fyrstendømme vokset sig stort, mere end én schuft steget op ad rangstigen, og mangen en ærlig mand bragt til fald."

Lidt senere overtager handels- og troldmanden, Mustaphus, scenen og fortæller i en monolog over 80 sider om sine vidunderlige varer, samtidig med at han udleverer alle slags opblæste, korrupte og naragtige lakajer. Gejstlige, embedsmænd, fallenter, konger og kejsere bliver leveret, så her har værket sit samfundskritiske og satiriske tyngdepunkt. Samtidig er det både morsomt og underholdende.

Mustaphus omtaler en besynderlig hændelse ved et bryllup i Andalusien, som skal nævnes her, fordi Kilian reagerer på den i sit modskrift:

"Har I ikke hørt det sidste nye? En opkomling havde forlovet sig med mange 
unge damer, for han ville gerne bekræftes, forsørges og give den gas en tid. Da viste det sig, at han kunne få en fed stilling som offentligt ansat, hvis han kunne komme i lag med datteren til den ledende embedsmand på stedet. Han ægtede hende og fik etatshatten på for så at løbe fra alle aftaler, helt efter etatshattens hovede. Men den gik ikke, han blev tvunget at at aftage den ene hoppe, lade de andre løbe, og måtte så lade som om, at han på ærlig vis havde bagt på den, han fik.

Hvis nogen knap så højt på strå, havde opført sig sådan, så var han blevet stemplet som en slubbert. Men på grund af etatshatten, så var det helt $\mathrm{i}$ orden. Som man siger: selv om to gør det samme, kommer det ikke altid ud på et. Det måtte en samvittighedsløs spytslikker sande, da han forlovede sig for at få en stilling, men i alles påsyn fik en på kassen af pigen, da han løb fra sit løfte. Det var ved et bryllup i Andalusien, og han tog sig det ikke så nær.

Hvor tit tager en ung mand sig ikke en kæreste? Men hvis han finder noget bedre, er han ikke forpligtet. Når han har etatshatten på, hvem kan så sige ham noget som helst på?"10

Johan Christophorus Kilian bebrejder Lassenius, at han her bryder sit løfte om diskretion og udstiller genkendelige personer i det "Fortunopolis" altså Glückstadt, som han ifølge Kilian henlægger hændelsen til.

I Lassenius' tekst falder øretæven i “Andalusien”, så Kilian tager altså fejl når han raser:

"Er det ikke at nævne nogen ved navn, når man skriver om noget, som er kendt mand og mand i mellem i både byen og på landet? Er 'Fortunopolis' ikke nemt for enhver at stedfæste, og gælder det ikke også forlovelsen, brylluppet, bruden, lussingen?"11

Kilian satiriserer videre over Nemo-figuren i dedikationen i Arcana.

"Jeg kunne her vise, hvordan Lassenius uden grund skælder ud på Nemo i sin tilegnelse, for Nemo har gjort ham mangen en god tjeneste. Han har i Utopia gjort ham til teologisk kandidat, decanen Nemo har gjort ham til magister i filosofi, ja, han har endda henvendt sig for at overrække ham en udnævnelse til tjeneste for biskoppen. Er det ikke skønne ydelser at få fra Nemo?"12

Kritikken bliver somme steder personlig og temmelig plat. For eksempel skal Lassenius uden skrupler have drukket øl og smøget tobak fra morgen til aften og taget gifte kvinder på brysterne, hvilket endda strider imod hans egne ord om det sjette bud osv. ... Han skal også have løbet fra regningen i et værtshus, som så blev betalt af en jøde, osv. ${ }^{13}$

Læseren må undre sig over Kilians skingre tone, urimelige bebrejdelser og platte anklager. En del er usandt. Lassenius har teologisk embedseksamen, han kritiserer ikke Nemo og han siger intet om, at en brudgom fik en på kassen i "Fortunopolis".

Den skråsikre tone bidrager yderligere til, at Kilian gør sig selv til grin. Han har tydeligvis heller ikke forstået, at der er tale om satire. På den anden side er det klart, at manden er både begavet og belæst. Han formulerer sig lejlighedsvist sylespidst og hans citatlyst viser dybt kendskab til Lassenius' og andre samtidige værker. Han kan derfor næppe være "Schüler", som han 
ellers kalder sig på titelbladet, og det går snart op for læseren.

Måske er denne bredside, et citat fra William Ames, en anden af tidens debattører, en indlagt ledetråd til hvem, der gemmer sig bag masken.

"Oh du blinde idiot, hvor har du gjort af din forstand, har dit vanvid over for de sagesløse helt bedøvet din fornuft og frataget dig din forstand. Du er blind og letsindig, du fjols, troløse hjælper, forfejlede $f_{x}$, du er en løgnhals, du som tænker alt for meget, du overkloge, enhver ser din tåbelighed, Oh højlærde, her bestrider du den klare sandhed, du opfører dig som en sitrende taskenspiller, som håber at hans hundekunstner aldrig kommer for en dag." Dette er ikke mine ord, men William Ames' i hans bog, der udkom for fire år siden, i 1662, og som gav Lassenius stor skrivekløe. Men hvorfor svarer han ikke Ames og forsvarer sit eget skrift?"15 16

Det gør han ikke, fordi Ames døde i 1662 kort efter at hans stridsskrift imod Lassenius var udkommet, så ham er der ingen grund til at tage til genmæle imod. Kilians bebrejdelse er uberettiget, og igen udstiller Kilian sig som en arrig spradebasse. Men samtidig er han sine steder både velformuleret og indsigtsfuld. Noget stemmer ikke.

Læseren vil, hvis han ellers er opmærksom, undre sig over modsigelserne, men Lassenius kan have mange gode grunde, ud over det stilistiske artisteri, til at lade sig gennemhegle af en fiktiv figur, som han måske selv har opfundet.

Ved at lægge William Ames bidske ord om sig selv i munden på Kilian får han sagt sin mening om Ames uden at dennes død står i vejen for kritikken. Også andre,

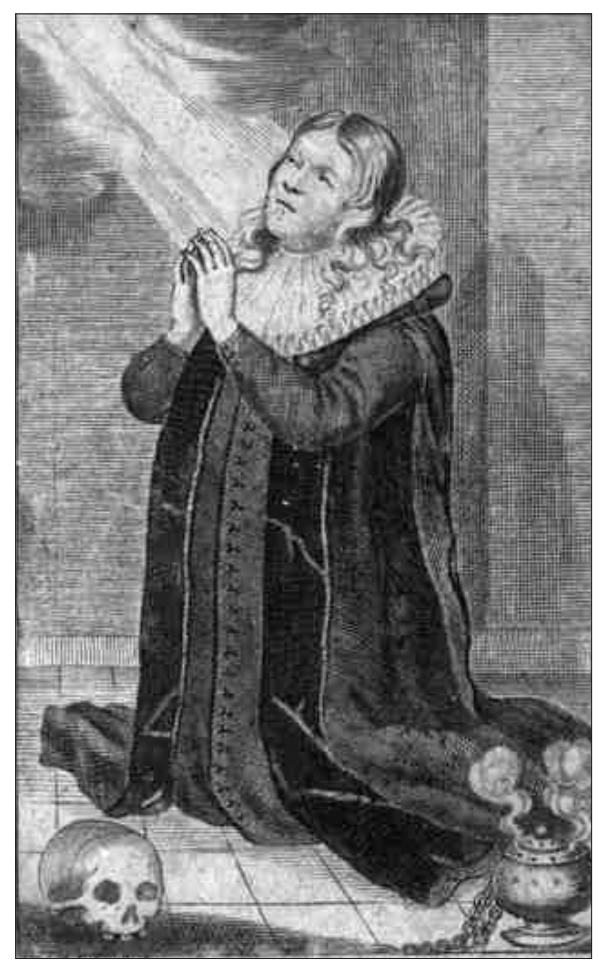

Den fromme Lassenius. Det Kongelige Bibliotek, Billedsamlingen, Müllers Pinakotek.

som kunne hænge sig i Lassenius vandel, eller har gjort det, bliver portrætteret som larmende brokkehoveder.

Kilians skrift er imidlertid andet og mere end et skinangreb. I nedenstående passage åbner Kilian for en intertekstuel sammenhæng, som de færreste nok havde set selv. Der sker under dække af, at Kilian kritiserer Lassenius for blot at gentage det, som andre har skrevet før ham:

"Men Lassenius skulle være blevet hjemme med sine statshatte, statsfrakker og statsbriller, han skal ikke tro, at han skriver noget særligt, det er jo ikke en bønne værd.

Philander har allerede i sine Satyrische Geschichten, især i den første og 


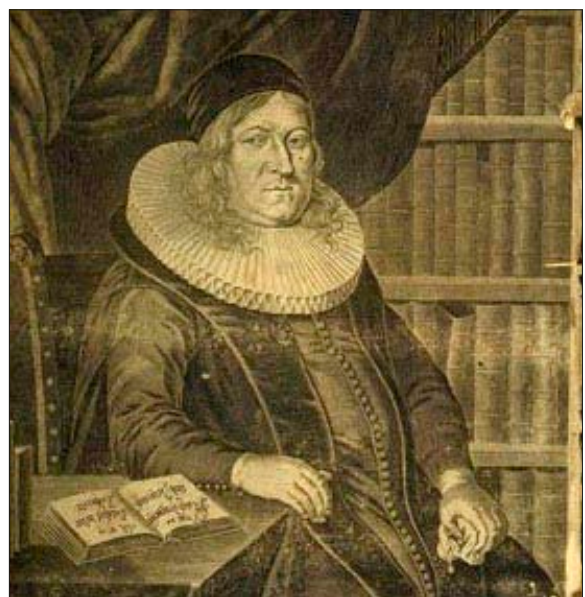

Lassenius i fuldt ornat. Det Kongelige Bibliotek, Billedsamlingen, Müllers Pinakotek.

den femte, som han kalder Ratio Status og Kauffhans, skrevet om disse ting, så alle kender til dem, og så der er jo ingen grund til at give bagerbørn brød, som man siger." ${ }^{17}$

Han henviser givetvis til "Wunderbahre Satyrische Gesichte verteutscht durch Philander von Sittewald”. Straßburg 1640, som også blev udgivet under afvigende titler. ${ }^{18}$ Den er net-tilgængelig under Gutenbergprojektet, ${ }^{19}$ og her fremgår, at Kilian angiver helt forkerte titler til første og femte "Geschichte". De hedder henholdsvis "Schergenteufel" og "Letztes Gericht”. Selv om Kilian altså igen udstiller sig som et fjols, så kan man ikke se bort fra, at han gør læseren en tjeneste ved at pege på forbindelsen til Moscheroschs tekst.

I den første "Geschichte” beskriver en rejsende først sin skuffelse over at opdage, hvor stor forskel der er på det, han har lært om gejstliges fromhed, statmænds retfærdighed og filosoffernes visdom og det hykleri, den korruption og naragtig- hed, han finder i verden. Han bliver af to præster i byen taget med til en excorcisme i en nærliggende kirke. Men her bliver alting vendt på hovedet, idet djævelen kun er lykkelig for at blive uddrevet af det slette menneske (en bøddel) og som vittigt fortæller om, hvordan der er i Helvede:

“'Er der digtere i Helvede', spurgte jeg. 'Ja, så sandelig er der det', svarede djævelen, 'de kribler og krabler ud og ind alle steder, så man for et par år siden måtte udvide deres kvarter. Der kan man se hvordan en ny sværmer, når han ankommer, indleverer en hilsen i håbet om, at de højstærede guddomme, som begejstrer digterne, Cerberus, Minos, Pasiphan, Megära, Medusa, Proserpina, Pluto, Aeolus, Rhamnusia, Neptun, Bacchus, Juno, Venus, Kupido, Mercur, Jupiter, Apollo, Diana og andre, vil være til stede og byde ham velkommen.'

Det gad jeg ikke at høre mere af, så jeg spurgte, hvad digterne kunne vente sig $\mathrm{i}$ Helvede. Så svarede ånden: 'Som du da kan spørge om, hvordan det går for sig $\mathrm{i}$ Helvede. Vent bare til du kommer herind, så vil du mærke det på din egen krop.'

Så svarede jeg, at det ville min Herre og Frelser, Jesus Christus, som har besejret djævelen, beskytte mig imod.

Så sagde han ophidset: 'Jeg mente, at I mennesker havde nok Helvede i livet, for I lever som om der slet ikke fandtes nogen Gud i Himmelen og som om I hellere end gerne ville i Helvede alle sammen. Nu skal jeg fortælle dig om al jeres infame gøren og laden på jorden.

Du vil helst høre rosende ord om digterne, fordi du selv skulle have været digter, men er det ikke sådan, at en digter lider så meget ve og smerte i sit hjerte, fordi hans hoved er fuld af ideer og ind- 
fald. Nogle bliver pint i Helvede ved, at de skal høre på deres egne og de andre digteres digterier, inspirationer og fjollerier og ligeså med musikere. Andre får deres løn ved, at de i hundreder og tusinder af år ikke får lov til at rette i deres vers.

Den ene slår sig for panden, den anden klør sig bag øret, en piller sig i næsen og en anden løber ni mil i sine tøfler og aner ikke om han er kommet ud af sit studerekammer. En fjerde har ingen blodårer, så hans tosserier stiger ham ikke til hovedet, med mindre han da har faet noget at drikke. Andre summer og brummer som en brumbasse i en kasse. Den næste vender øjnene opad, som en ged, der bliver stukke af en bi og så kan de alligevel ikke finde ud af, om man skal sige vultus eller facies, scripsit eller scribsit, sumptus eller sumtus, optimé eller óptime, sollicitus eller solicitus eller om den ene stavelse er for lang eller den anden for kort." 2021

Senere klager djævelen over, at djævle bliver overbebyrdet:

"Hvad der virkelig går os på nerverne er, at I mennesker og især tyendet, har gjort jeres infame opførsel til det normale. For før i tiden tilskev man alt, hvad det var vanvittigt til 'Ingen', men nu er alting de arme djæveles skyld. Alt det som ingen vil tage på sin kappe, det beskylder man Fanden for: Fanden stå i det, det er djævelens værk, han har givet sig Fanden i vold, der er gået en djævel i ham, hvad Fanden er det? Hvem Fanden har gjort dette eller hint? Hvilken djævel har sagt dette? Hvilken djævel har forrådt mig, Fanden tage den skrædder, som har syet mig noget elendigt tøj, det ene for kort det andet for snævert og så har han endda bestjålet mig. Skrædderne giver os evig og altid en verden af problemer, og hvor meget forslår de så til gengæld i Helvede?

De arme djævle bliver altså behandlet som gadeskidt og tilmed set ned på, på trods af, at vi altså ikke er så sultne, at vi tager imod alt, hvad vi får tilbudt.

Hvis en tjener har gjort noget forkert, så 'Fanden tage ham', siger I så. Men I skal vide, at Djævelen ikke har lyst til at tage nogen af jer, for de fleste er værre en Fanden selv, så de er til ingen verdens nytte i Helvede, de kan hverken koge eller brase.

Fanden tage disse italienere! Men han betakker sig, for disse folk har let til kniven og man ved aldrig,hvornår man har en siddende i ryggen.

Fanden tage disse Spaniere! Men da alle kender til deres herskesyge, vil de vel også underlægge sig Helvede! Til tyrkerne med dette rakkerpak, som maurerne kan styrke deres hære af janitscharer og omskårne med." 2223

Henvisningen til "Ingen” rimer på Lassenius dedikation til "Herr Nemo aus Allerhausen”. Måske har Lassenius fået idéen her.

Kilian gennemhegler Lassenius igen og igen, men samtidig perspektiverer han Lassenius' tekst med henvisningen til en af Lassenius forbilleder, nemlig forfatteren og tænkeren Johann Michael Moscherosch, 1601-69 som altså bruger pseudonumet Philander.

Femte "Geschichte" låner både form og indhold fra Dantes Inferno og Johannes' Åbenbaring og beretter om, at alle stænder, erhverv og aldersgrupper af den ene eller anden grund ender i Helvede. Kvinderne får følgende salut:

"Alt dette så og hørte jeg udmærket, for jeg havde stillet mig op på en lille bakke. Men 
så hørte jeg skrigen og råben nedenfor og inden jeg fik mig forføjet, så jeg en flok skønne kvinder komme imod mig, idet de overdængede mig med sjofelheder og uartige talemåder, fordi jeg ikke viste respekt og underdanighed over for fruentimmerne, for selv i Helvede, som på jorden, er kvinderne lige så indbildske og forfængelige og de mener altså, at man skal varte dem op som en tjenstivrig slave. De var i et vældigt humør, for i deres nøgenhed så de knaldgodt ud og de trak alle, der kiggede på dem, rundt ved næsen.

Men da de indså, at dette var Dommens Dag mistede de pludselig modet, og de bebrejdede deres egen skønhed at være skyld i deres synder, og så gik de med anstand roligt den lige vej ned gennem dalen. Mange af dem, som var mildt opdraget og ikke var vant til at gå alene og barfodet, kaldte på deres tjenere og lakajer og forlangte at blive taget $i$ hånden eller båret på armen. Men disse blev samtidig bebrejdet af deres egne herrer, at de havde gjort deres koner til letlevende skøger og lokket dem på afveje med lumskelige kærlighedsbreve." 2425

Arcana rummer ingen angreb på det smukke køn, måske fordi Lassenius netop gik i giftetanker i 1666. Men Moscherosch lader ikke lægerne i fred, som ej heller i Arcana, og giver dem ren besked:

"Imens hørte jeg råben og skrigen fra en flok, der forfulgte en læge. Det var de af hans patienter, som han havde taget livet af, før tiden var inde, og de råbte op om mord og skubbede ham hen til domstolen, så han kunne drages til ansvar. 'Ja, ja' sagde han, 'her er ingen nødsituation, jeg trøster mig med det gode, gamle ordsprog: 'Selv når en advokat eller en læge piner nogen til døde, så skal han ikke stå til regnskab."

Det er den rene ynk, at en læge aldrig har det godt med mindre andre har det dårligt. For at skabe ro trådte en betalt prokurator frem og sagde: 'Da ingen, bortset fra Gud, har mere magt end lægerne, så skal de ikke stå til regnskab for deres gerninger.' 'Så sand, så sandt', sagde en anden doktor, 'og hvordan skulle det gå her i verden, hvis alle menneskene blev ved med at leve og ikke blev udrenset, lutret og afmønstret af os læger? Ville verden så ikke være propfuld at idioter?'”2627

Og så videre. Philanders værk har båret forskellige titler. Kilian skriver bare: "Philander hat in "seinen satyrischen Gesichten”...” og synes at forudsætte teksten kendt. Kun i førsteudgaven fra $1640^{28}$ indgår imidlertid ordet "satyrisch", hvilket kan være grunden til referencen.

Petroinus' "Satyricon", al komisk litteraturs moder, udkom i en kapitelinddelt udgave i 1664 og blev sikkert slugt af den latinkyndige Lassenius. Det ser ud til, at han lader sig inspirere af både fortællestilen, hvor poesi og prosa veksler, og af stedet, mens han bortset fra enkelte latrinære gloser, holder sig på sikker afstand af Petronius' uartige, men meget morsomme beretning.

\section{De mystiske førsteudgave}

I fortalen til Arcana henvender Lassenius sig til "tysksindede, sandhedselskende, højtærede læsere” og han placerer sig dermed på samme side som von Zesen, Moscherosch og de mange sprogselskaber, der kæmpede for, at det tyske sprog fik mere plads i digtningen, som fortrinsvis blev skrevet på latin. Dette har nok ikke begrænset læserska- 

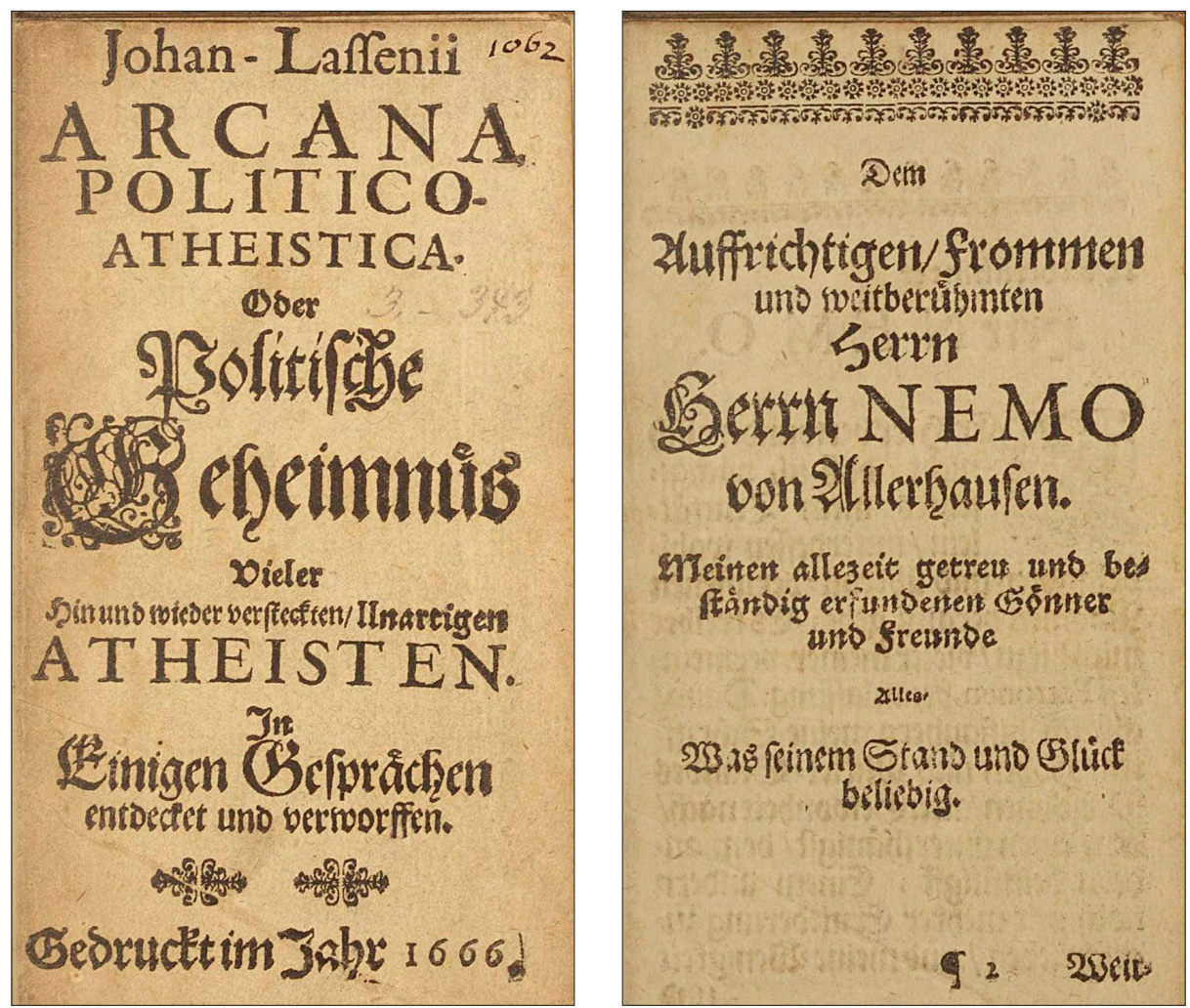

Titelblad og forste side afforsteudgaven fra 1666 af Johannes Lassenius' Arcana, der ligesom hovedparten af den europeiske litteratur fra for 1700 er tilgengelig via ProQuest: "Early European Books". Her igen Det Kongelige Biblioteks eksemplar i denne internationale digitale samling: <eeb.chadwyck.co.uk>.

ren væsentligt og værket udkom da også som nævnt to gange i 1666 og mange gange siden hen. Samuel Saur trykte den så sent som 1795 i Philadelphia, USA. ${ }^{29}$

I 1703 skriver en ukendt udgiver i en indledning bl.a:

"Den første udgave, som kom for dagens lys år 1666, vil kunne dømmes hårdt på grund af hemmeligholdte forhold af denne udgave, idet nemlig den salige hr. forfatteren, så vidt han kunne, tilbagekøbte alle solgte eksemplarer, fordi han altså fik betænkeligheder over at gøre dem almindelig kendt." ${ }^{30}$

Hvilke hemmeligheder, udgiveren nu lokker med fremgår ikke. Men det kan tænkes, at han har taget Kilians modskrift for pålydende, hvor han jo henlægger den omtalte lussing til "Fortunopolis", og så har formodet, at der har stået sådan i den nu forsvundne førsteudgave af Arcana.

Mærkværdigvis skriver han "Andalusien”, som i alle andre udgaver, vi 


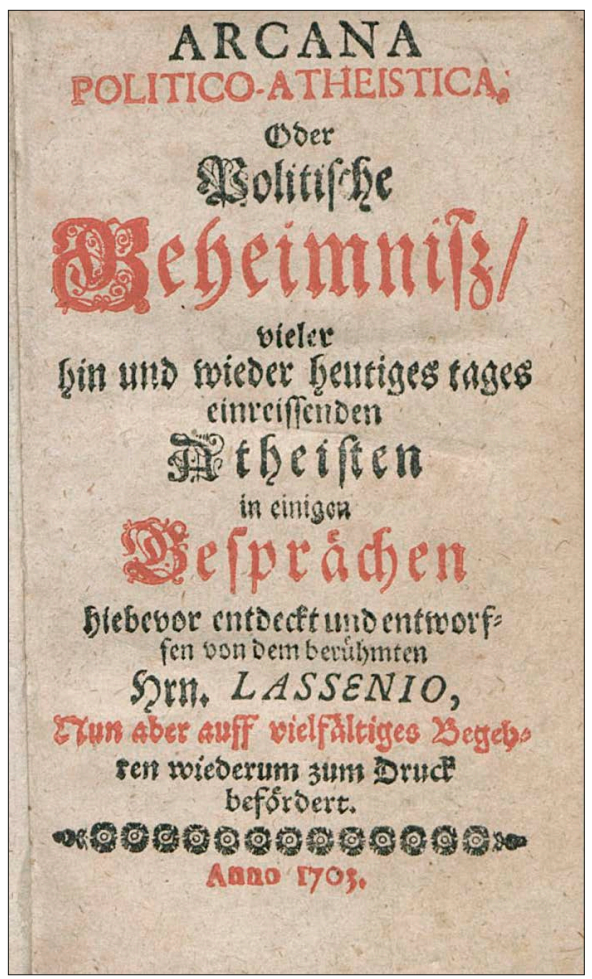

Arcana, 1703-udgaven.

kender, i sin 1703 udgave. Den pinlige førsteudgave skulle Lassenius altså i følge udgiveren have forsøgt at indsamle, fordi den medførte berettiget kritik. Det lyder interessant, men det er ikke sandsynligt. For det første ville blot et enkelt undsluppet eksemplar være nok til at gøre ham livet surt, og for det andet ville indsamlingen i sig selv være en offentlig tilståelse af, at han havde forløbet sig. Sagen er at sammenligne med landsbysladder, og er derfor ikke noget alvorligt problem for Lassenius. Sidst ville det ligne den ærekære og polemiske Lassenius dårligt at forsøge at indhente sine ord på denne klodsede måde. Snarere har udgiveren af
1703 udgaven ikke gennemskuet Kilians rolle som Lassenius' andet talerør, så han hopper på det litterære svindelnummer og finder så på forklaringen med den forsvundne originaludgave. Men den har nok aldrig eksisteret, og det har da heller ikke været muligt at finde bare et enkelt ovelevende eksemplar af denne udgave i biblioteker fra Hamburg til Greifswald.

Kilians mange fejl er tilsigtede ledetråde, som skal bringe læseren på sporet af hans litterære funktion og Arcanas sande indhold. Spor af en sag om brudt ægteskabsløfte har hverken været at finde i arkiverne i Glückstadt eller i Schleswig. Men det udelukker ikke helt, at historien har haft virkelige aktører, som får deres bekomst i Arcana.

Lassenius kan have flere grunde til under falsk navn at udgive et stridsskrift imod sig selv i samme år, som Arcana udkom.

Kilians urimelige bebrejdelser kan som nævnt være en latterliggørelse af hans modstandere som overfladiske skrighalse. Men samtidig får han skabt røre om sit værk, og dette kan være grunden til, at han, eller en pirattrykker, kunne sende et andet oplag på markedet samme år. Der er altså tale om et salgstrick.

Samtidig rummer Kilians tekst for den vågne læser en nøgle til Arcana, og Lassenius indrømmer, at han har hugget Nemostuntet fra Morscherosch, ja, hans samfundskritik lægger sig i så høj grad i forlængelse af dennes, at han fremstår som litterært forbillede for Lassenius. Så der er tale om en nobel kildehenvisning.

En dristig, dybdepsykologisk tolkning kunne være, at Kilian i virkeligheden repræsenterer Lassenius' dårlige samvittighed, som så vender tilbage og svinger ferlen over hans syndige hoved, for Lassenius 
var som troende protestant helt sikkert bevidst om sin egen syndighed.

Alle som kender gådens løsning er døde og borte, og vi kan kun gætte. Helt sikre på, at Kilian kun er en litterær figur, kan vi ikke være.

Og det er nok heller ikke meningen.

Tak til lektor emerita Vibeke Winge for gennemlasning, konstruktiv kritik og gode ideer.

\section{Litteratur}

Ames, William, Markgraf zu Brandenburg Friderich Wilhelm, and Johann Lassenius. Die Sache Christi und seines Volcks/gerechtfertiget: Oder Eine Antwort zu einem Stul. Stud. Johannes Lasseni, welcher sich vermessen hat/ eine lügenhafftige Historie von der newen Secte der Quaker (so genant) außzu geben: In welcher Antwort/sie zusammen mit ibrer Lehre und Anfangel gerechtfertigt seyn/ und seine lügenhafftige und rasende Beschultigungen entkent/ und verurtheilet; Hir ist auch eine Antwort beygefüget auf einige grobe Beschultigungen/ mit welche er die Quaker verwiesen hat in der vorgemelten Historie; Nebenst noch einer andern Antwort auff etliche Beschultigungen gegen die gemelte Quaker/ außgegeben in einem Buch/genandt/ Neuwe Schwarmgeister Brüte/ [et]c. Als erstlich mit dem bösen Auffrubr/ durch die fünffte Monarchey Männer zu Londen geschehen. Zum andern/mit dem Fall von James Naylor. Und zum dritten/ mit der Eytelkeit und Unsinnigkeit von Johan Gilxin: Und endlich ... auffeinig böß Vorgeben ... von Johann Berckendal ... [S.1.]; Amsterdam, 1662.

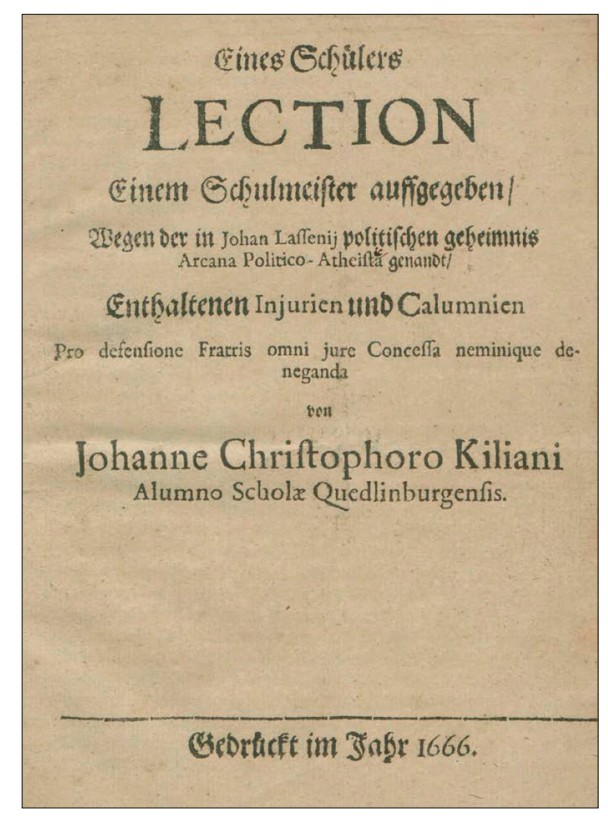

Kilians bog er bl.a. tilgangelig via ProQuest: "Early European Books", hvortil Det Kongelige Bibliotek har digitaliseret sit eksemplar (Hielmstiernes samling, 276 40).

Kilian, Johann Christoph. Eines Schülers Lection Einem Schulmeister Auffgegeben, Wegen Der in Johan Lassenii Politischen Geheimnis Arcana Politico-Atheista Genandt, Enthaltenen Injurien Und Calumnien Pro Defensione Fratris Omni Jure Concessa Neminique Deneganda, 1666.

Lassenius, Johann. Arcana Politico-Atheistica, Oder Politische Geheimnisz, Vieler Hin Und Wieder Heutiges Tages Einreissenden Atheisten: In Einigen Gesprächen Hiebevor Entdeckt Und Entworffen von Dem Berühmten Hrn. Lassenio. S.I.], 1703. http://resolver.staatsbibliothek-berlin.de/ SBB0000698E00000000.

Lassen, Johannes. Arcana politico-atheistica, oder Politische Geheimnüs vieler hin und wider versteckter, unartigen Abteisten, in einigen Gesprächen entdeckt und verworffen, 1666. 
Moscherosch 1640. Johann Michael Moscherosch: Gesichte Philanders von Sittewald. Herausgegeben von Felix Bobertag, Berlin; Stuttgart: W. Spemann, [.o. J.], [Deutsche National-Litteratur, Band 32]. Erstdruck Unter Dem Titel: »Les Visiones de Don Francesco de Quevedo Villegas. Oder Wunderbahre Satyrische Gesichte Verteutscht Durch Philander von Sittewalt «, Straßburg (Johann Philipp Mülbe) 1640.

\section{Noter}

1 Lassen, Arcana politico-atheistica, oder Politische Geheimnüs vieler hin und wider versteckter, unartigen Abteisten, in einigen Gesprächen entdeckt und verworffen.

2 Kilian, Eines Schülers Lection Einem Schulmeister Auffgegeben, Wegen Der in Johan Lassenii Politischen Geheimnis Arcana Politico-Atheista Genandt, Enthaltenen Injurien Und Calumnien Pro Defensione Fratris Omni Jure Concessa Neminique Deneganda.

3 "Dem Aufrichtigen/frommen und weitberühmten Herrn

Herrn NEMO von Allerhausen. Meinen allezeit getreu und beständig erfundenen Gönner und Freunde alles Was seinem Stand und Glück beliebig.

\section{Lassen 1666, p. 2:}

Weitberühmter

Herr NEMO

Der Herr verwundere sich nicht/daß ich nachgeseztes mein Tractatlein/unterdessen woblbekandten und überall-berufenen Nabmen heraus gebe; Es treibet mich hierzu vieler meiner vermeinten Patronen veranlassung; Dann / alß ich bißanhero meine Schriften Hohen und Mittel-Standes Persobnen/alter Gewohnheit nach/ dem einen untherthänigst/dem anderen demutigst; Einem anderen noch mit mehrer
Vol. 32. Deutsche Nationalliteratur 32. Berlin, n.d.

Petronius Arbiter, Knud Schwanenflügel, and J. V. Lind. Satyricon. Hermann, 1945.

"Philanders von Sittenwald Wunderliche Und Wahrhaftige Gesichte - Erster Teil von Hans Michael Moscherosch - Text Im Projekt Gutenberg." http://gutenberg. spiegel.de/buch/philanders-von-sittenwald-wunderliche-und-wahrhaftige-gesichte-erster-teil-2704/1.

Erniederung zugeschrieben/und meine Wenigkeit und studia denenselben auffs beste recommendieret ist mir allezeit zur Antwort geworden daß NIEMAND sich finde/dem nicht mit aller Gewogenheit hier zugethan verbleibe;

5 Lassen 1666, p. 9: Einige werden auch für gewiß halten/ich habe diesen oder jeden gemeinet und angestochen; Falz es mir dann gemeiniglich also ergebet/ daß viele Misgönstige / aus dem besten Honig meiner Schrifften/ einen Gifft erzwingen pflegen; Deswegen protestiere hiermit vor der ganzen Welt/ daß ich diesen Gesprächen niemands in specie gemeinet/ niemands gelästert noch getadelt;

6 Sammenlign med Petronius Arbiter, Schwanenflügel, and Lind, Satyricon. Side1 19 n.f.

7 Lassen 1666, Erstes Gespräch, p. 1: DIE einige Zeit / mit jedermanns (absonderlich aber / der in etwas höher von der Erden fliegenden / und auff das Zukunftige mehr dann auff das Gegenwertige sehenden) Verwunderung am Firmament des Gestirnten Himmels / nicht ohn Schrecken und Bestürzung / Fuer / Krieg Noht und Todt dräuende Kometen / hatten allbereit angefangen / an vielen Orten ihren Effect zu erreichen; so daß es auß Furcht der Nachkommender Dinge / 
und auß besorglicher dependentz, einiger / in der geheimen Estats-Stuben allnoch geschmiedeter desseinen / bei vieler Million seuffzenden / und über den Schaden Josephs herzlich klagenden Seelen heist; Ihr Berge fallet über uns / und ihr Hügel bedecket uns

8 Lassen 1666, Drittes Gespräch, p. 62: ... / allerhand außländische Kauffleute / mit unterschiedener Art wahren / denen sich hinzugesellet / allerhand Comedianten, Gauckel- und Taschenspieler / Quaksalber / Zahnbrecher / Glückstöpffer / und dergleichen Geschmeiß und Gesinde / so zu anders nicht dienet / dann dem gemeinen Mann / und ingesamt Einwohnern dieses Ortes / fein artlich / und mit einer Guten Manier / das Geld auß dem Beutel zu ziehen

9 Lassen 1666, p. 88: ... der Hut aber / dienet zu nichts anders / dann nur sub specie recti, die Leute zu dementieren, und durch den eusserlichen Schein zu fangen / daß man meinen solte / alles was von einem solchen / mit dem Stands-Hut bedeckten Statisten redet und getrieben wird / sey alles Englisch / Himlisch und Göttlich / da doch die höchste Bosheit darunter verborgen / und dadurch nicht lana tantum, sondern ovismit all gesuchet wird / durch diesen Standts-Hut / ist mancher bis anhero hoch gestiegen; Manches Königreich und Fürstentumb / groß und herrlich werden; Mancher Lumpenhund groß / und mancher redlicher Mann unterdrücket

10 Ibid., 109.

11 Kilian 1666, p. 4.

12 Ibid., 11.

13 Ibid., 10.

14 Ames, Friderich Wilhelm, and Lassenius, Die Sache Christi und seines Volcks/ gerechtfertiget, 1662.

15 Kilian 1666, p. 5: Und möchte ich in diesem Fall Lassenium wol anreden/ als William Ames in seinem Scripto contra Lassenium: Oh du blinder Narr/ wo ist dein Verstand, hat deine Unsinnigkeit wieder die Unschuldigen/ deine Vernunft ersoffen/ und dich deines Verstandes gänzlich beräubet? Du bist blind und muthwillig/ du narr/ Lügenhafter Helffer, schlechter Tropf/ ich sage es ausdrücklich/ dass du ein Lügner bist / du nimis Sapiens / alzukluger Mann/ wie offenbar ist deine Torheit? 0 Wundergelehrter Man / Alhier hastu den blossen Warheit wiederredet / du trägest dich wie ein bebender Gauckler/ voll alles Betrugs /dürfest dennoch hoffen/ dass deine Gaucklerey nicht sollte an das Licht kommen. Dis sind nicht meine Wort / sondern des William Ames, welches Buch schon vor vier Jahren/ Anno 1662. gedrucket und hat Lassenius so grosse Lust Bücher zu schreiben/ davon er vorgiebet in der Vorrede der Gespr. Spiel/ Er erfülle hiermit seinen Beruff/Scilicet / Warumb antwortet er nicht gedachtem Ames und defendieret sein Scriptum.

16 "Philanders von Sittenwald Wunderliche Und Wahrhaftige Gesichte - Erster Teil von Hans Michael Moscherosch - Text Im Projekt Gutenberg." Der findes i øvrigt en anden William Ames, der også var både teolog og forfatter. Han døde imidlertid i 1633.

17 Kilian 1666, p. 6: Und hatte Lassenius mit seinem Stadts-Hüten/ Stadts-Mänteln und Stadts Brillen wol zu Hause bleiben mögen/ es ist nichts neues/ wie er sich einbilden mag/ dass er gefunden/ non quod pueri in Faba. Philander hat in seinen satyrischen Gesichten/sonderlich in den 1 und 5 Gesicht / so Ratio Status und kauffhans heisset / längst von solcher Materia geschrieben/ und ist jedermannilich bekand/ dass es hier von Lassenio heisset / was in der Grammatic sub Regula ad Locom stehet: Noctuas Athenas portat.

18 Moscherosch, Johann Michael Moscherosch: Gesichte Philanders von Sittewald. Herausgegeben von Felix Bobertag, Berlin; 
Stuttgart: W. Spemann, [.o. J.], [Deutsche National-Litteratur, Band 32]. Erstdruck Unter Dem Titel: »Les Visiones de Don Francesco de Quevedo Villegas. Oder Wunderbahre Satyrische Gesichte Verteutscht Durch Philander von Sittewalt«, Straßburg (Johann Philipp Mülbe) 1640.

19 "Philanders von Sittenwald Wunderliche Und Wahrhaftige Gesichte - Erster Teil von Hans Michael Moscherosch - Text Im Projekt Gutenberg."

20 "Philanders von Sittenwald Wunderliche Und Wahrhaftige Gesichte - Erster Teil von Hans Michael Moscherosch - Text Im Projekt Gutenberg," kap. 2.

21 Hat es auch Poeten in der Hölle? fragte ich.

$\gg$ Ja freilich, antwortete der Teufel, es wimmelt und wibbelt darin; darum hat man vor einigen Jahren ihr Quartier erweitern müssen. Allda ist zu sehen, wie, wenn ein neuer Schwärmer von ihnen ankommt, er seine Begrüßungsschreiben einhändigt in der Hoffnung, die erhabenen Gottheiten, die die Dichter begeistern, wie Charon, Cerberus, Minos, Pasiphan, Megära, Medusa, Proserpina, Pluto, Aeolus, Rhamnusia, Neptun, Bacchus, Juno, Venus, Kupido, Mercur, Jupiter, Apollo, Diana und andere zu finden und zu begrüßen.« Weil mich das ein wenig verdroß, fragte ich, was denn die Poeten in der Hölle zu gewärtigen hätten? Da antwortete der Geist: »Was darfst du viel fragen, wie es in der Hölle zugeht? Du wirst es schon erfahren, wenn du hineinkommst. « Darauf sagte ich, davor wird mich mein Herr und Heiland Jesus Christus, der den Teufel überwunden hat, wohl behüten. Darüber tobte der Geist und sprach: »Ich meinte, ihr Menschen hättet bei und an euch selbst Hölle genug, denn ihr lebt so auf der Welt, als ob kein Gott im Himmel wäre und ihr mit aller Macht in unsere Hölle wolltet. Ich will dir eure höllischen Handlungen, die ihr auf Erden verübt, sein nacheinander herzählen. Du hörst die Poeten so gern loben, weil du auch einmal einer hast sein sollen: ist es nicht so, daß ein Poet soviel Pein und Marter in seinem Herzen leidet, sovielerlei Einfälle er im Kopfe hat? Etliche werden in der Hölle zur Belohnung gepeinigt, wenn sie ihrer Mitmeister und Mitgesellen Werke und Gedichte, Grillen und Possen lesen hören: und so geschieht es auch bei den Musikanten. Etliche haben ihre Belohnung darin, daß sie nach vielen hundert und tausend Jahren nicht aushören können, ihre Verse zu revidiren und zu corrigiren. Einer giebt sich mit der Faust einen Stoß vor die Stirne; ein anderer kratzt sich hinter den Ohren; einer krabbelt sich in der Nase; ein anderer läuft neun Meilen Wegs in seinen Pantoffeln und weiß nicht, $\mathrm{da}$ er aus seiner Studierstube gekommen ist; ein anderer hat keine Ader (das heißt, die Grillen wollen ihm nicht steigen), er habe denn getrunken. Ein anderer seufzt; ein anderer summt und brummt wie eine Hummel in der Trommel; ein anderer verkehrt die Augen wie eine Geiß, die geschlagen oder gestochen wird, und dennoch können sie noch heut zu Tage nicht finden und errathen, ob man sagen solle vultus oder facies, scripsit oder scribsit, sumptus oder sumtus, optimé oder óptime, sollicitus oder solicitus, und ob diese oder jene Silbe lang oder kurz ist.

22 Ein Ding ist, was uns über die Maßen verdrießt, das euch Menschen, insonderheit den Dienstboten, in euren höllischen Welthändeln ein gar gewöhnliches ist. Während vordem alles, was widersinnig herging, dem 'Niemand' zugeschrieben wurde, schiebt man jetzt alles auf die armen Teufel. Was sonst niemand will gethan haben, das hat der Teufel gethan: das thu' der Teufel! Alles dem Teufel zu! Das wolle der Teufel! Was zum Teufel ist das? Welcher Teufel hat das gethan? Welcher Teufel hat das gesagt? Welcher Teufel 
hat mich verrathen? Der Teufel hole den Schneider, wie hat er mir das Kleid verdorben! Wie hat er mich solange hingehalten! Wie hat er mir das zu kurz, das zu eng gemacht und mich bestohlen! Und es ist uns niemals mehr Unglück gewünscht, als der Schneider wegen; weswegen sie denn auch als Erben und liebe Kinder bei uns sein möchten.

Die armen Teufel also werden eben schlecht behandelt und schändlich verehrt, obschon wir doch nicht so hungrig sind, daß wir alles, was man uns anwünscht, annehmen würden.

Hat ein Lakai etwas Uebles gethan, ei, daß ihn der Teufel hole! sprecht ihr dann. Aber wisset, der Teufel begehrt deren keinen; denn der größte Theil unter ihnen ist viel ärger als die Teufel, sie sind uns ein sehr unnützes Gesindel in der Hölle, die weder zum Sieden noch zum Braten taugen.

Der Teufel hole diesen Italiener! Aber wisset, er bedankt sich für diese Ehre; denn ein Italiener dürfte einem unvermerkt einen Dolch in den Buckel stoßen.

Der Teufel hole diesen Spanier! Aber weil der Spanier Herrschsucht schon so bekannt ist, dürften sie sich wohl gar der Hölle unterfangen wollen. Zu den Türken mit all diesem Gesindel, denn er bedarf der Mauren, um die Heere der Janitscharen und Beschnittenen damit zu stärken! «

23 "Philanders von Sittenwald Wunderliche Und Wahrhaftige Gesichte - Erster Teil von Hans Michael Moscherosch - Text Im Projekt Gutenberg," chap. 2.

24 Ibid., chap. 6.

25 Dies alles sah und hörte ich gar wohl, dieweil ich mich auf eine Höhe gestellt hatte. Bald aber vernahm ich ein Geschrei unter meinen Füßen, daß ich Platz machen und weichen sollte, und ehe ich ordentlich herab kam, sah ich einen Haufen vortrefflich schöner Weiber einherkommen, welche mich Unflat und grober Flegel schalten, weil ich den Frauenzimmern nicht mehr Ehre und Recht anzuthun wüßte (denn selbst in der Hölle noch, wie auf Erden, haben die Frauenzimmer diese Einbildung und Eitelkeit an sich, daß sie meinen, man müsse sie ehren und ihnen mit sklavischer Dienstbarkeit aufwarten). Sie waren lustig und guter Dinge, weil sie sahen, daß sie nackend, so schön und so wohlgestalteten Leibes daher traten, und daß alle Welt sie anschauen und lieben würde. Bald aber entfiel ihnen der Muth, als sie merkten, daß dies der Tag des Zorns wäre, und daß ihre Schönheit sie bereits innerlich im Gewissen ihrer Sünde anklagte, weswegen sie den Weg grade aus, doch mit langsamen, sittsamen Gange, thalab nahmen. Viele unter ihnen, die in ihrem Leben zärtlich und weich erzogen und nicht gewohnt waren, barfuß oder ohne Gesellschaft zu gehen, die riefen ihren Lakaien und Hofmeistern zu, sie sollten sie unter den Armen und auf den Armen leiten und führen. Dieselben aber waren anderwärts mit Geschäften beladen, indem sie von ihren Herren angeklagt wurden, daß sie während des Lebens auf der Welt ihren Weibern zu heimlicher Leichtfertigkeit und Ueppigkeit Anlaß gegeben und diesen die Buhlenbriefe hier und da bestellt hätten.

26 "Philanders von Sittenwald Wunderliche Und Wahrhaftige Gesichte - Erster Teil von Hans Michael Moscherosch - Text Im Projekt Gutenberg," chap. 6.

27 Unterdessen vernahm ich ein Geschrei vieler Leute, welche, als ich mich umsah, einem Arzt nachliefen. Es waren diejenigen, denen der böse Doctor, wie man sagt, den Rest vor der Zeit gegeben hatte: sie schrieen ihm Mord nach und stießen ihn derb gegen den Richterstuhl zu, um sich ihretwegen zu verantworten. »O ja! o ja! sprach er; nur immer her; es wird hier noch keine Noth haben, ich getröste 
mich des heilsamen Spruches: wenn auch der Arzt und Advocat mag einen zu Tode martern, so ist er darum noch nicht schuldig Rechenschaft darüber zu geben.[...] Es ist ein elend Ding um einen Arzt, dem nimmer wohl ist, es sei denn den andern Leuten übel. Um den Lärm zu stillen, trat ein mit Geld bestochener Fürsprecher herbei und sprach: »Weil nächst Gott keinem Menschen mehr Macht gegeben ist als einem Arzt, so sind sie auch den Menschen ihrer Handlungen wegen Rechenschaft zu geben nicht schuldig. « »Das ist wahr, sprach ein anderer Doctor der Arzenei; und wohin sollte es auf Erden kommen, wenn alle Menschen leben blieben und nicht durch uns gereinigt, geläutert, ausgemustert und purgirt würden? Wäre dem nicht also - die Welt würde voller Narren werden.«
28 Moscherosch 1640.

29 Wilhelm Rahe, Johannes Lassenius (163692), Beiträge Zur Förderung Christlicher Theologie (Gütersloh, 1933),side 175 angiver følgende udgivelsesår 1672, 1686, $1693,1696,1703,1717$. Nedertysk oversættelse 1738.

30 Lassenius 1703, p. 10-11.

Weme die Fata der erstern Edition so Anno 1666 ans Licht kam/in etwas bekandt/ der dörffte ungehörter Sachen von dieser jezigen Divulgation ein hartes Urtheil fällen/indeme nemlich der sel. Hr. Verfasser aller ersteze Exemplaerien/ so viel er ihrer habhaft werden können/ wieder an sich erhandelt / und also solche gemein zumachen ein Bedenken getragen. 